\title{
Blieschow on Jasmund - geomorphology and glacigenic landforms: keys to understanding the deformation chronology of Jasmund
}

\author{
Anna Gehrmann ${ }^{1}$ and Chris Harding ${ }^{2}$ \\ ${ }^{1}$ Institut für Geographie und Geologie, Universität Greifswald, Friedrich-Ludwig-Jahn-Str. 17a, 17487 Greifswald, Germany \\ ${ }^{2}$ Department of Geological and Atmospheric Sciences, Iowa State University, Ames, IA 50011, USA
}

Correspondence: Anna Gehrmann (anna.gehrmann@uni-greifswald.de)

Relevant dates: $\quad$ Published: 15 August 2019

How to cite: $\quad$ Gehrmann, A. and Harding, C.: Blieschow on Jasmund - geomorphology and glacigenic landforms: keys to understanding the deformation chronology of Jasmund, DEUQUA Spec. Pub., 2, 11-17, https://doi.org/10.5194/deuquasp-2-11-2019, 2019.

Abstract:

The late Weichselian glacitectonic framework of the Jasmund peninsula forms surface expressions of subparallel ridges and elongated valleys in between. Geomorphological mapping and landform analyses based on lidar-derived digital elevation models (DEMs) give rise to a revised genetic model for Jasmund, including three evolutional stages that are characterised by different ice flow patterns.

1 Glacial geomorphology of the Jasmund peninsula

The Jasmund peninsula is situated in the NE of Germany's largest island, the isle of Rügen. It is a major example of large-scale glacitectonic folding and thrusting (Groth, 2003; Müller and Obst, 2006; Ludwig, 2011; Gehrmann et al., 2017). The structural framework shows a glacitectonic complex, which was probably formed after the Last Glacial Maximum (MIS 2) in response to a readvance of the Scandinavian Ice Sheet (SIS) during the Pomeranian phase (W2, 17.6 ka BP) (Müller and Obst, 2006; Litt et al., 2007; Gehrmann and Harding, 2018). It has a surface expression in the form of two major sets of subparallel composite ridges (Fig. 1). These ridges can be well observed from the elevation Goldberg near Blieschow $\left(54^{\circ} 31.254^{\prime} \mathrm{N}, 13^{\circ} 34.996^{\prime} \mathrm{E}\right)$. The southern set is arcuate, presumably concave to the former glacier margin in the southeast. It consists of SW-NEtrending ridges. Furthermore, in the northeastern district of the southern set, the crest lines show a crenulated character. The northern complex is arcuate, too, but concave to the
NE. Its elongated landforms have an approximately NW-SE trend. The northern ridge set appears to be partly truncated and superimposed by the southern set.

Both composite ridge sets are locally covered by depressions, which often form lakes. The lakes are potential karst phenomena, kettle holes, or both (e.g. Paulson, 2001; Groth, 2003). The effect of these depressions is especially noticeable at the boundary between the southern and the northern ridge set and at the area SE of the highest elevation, Piekberg (160.9 m a.s.1.).

Areas forming morphological highs SE and SW of the southern ridge set (undifferentiated landforms) differ from the composite ridges by their chaotic ridge pattern. Although there is not yet a lot of evidence, these landforms might be interpreted as hummocky moraines (Gehrmann and Harding, 2018).

The western area of the Jasmund peninsula is characterised by glacifluvial deposits and till from a Weichselian ground moraine (W2 following Niedermeyer et al., 2010). Areas of Holocene swamps/fenland cover parts of the river valleys, the 


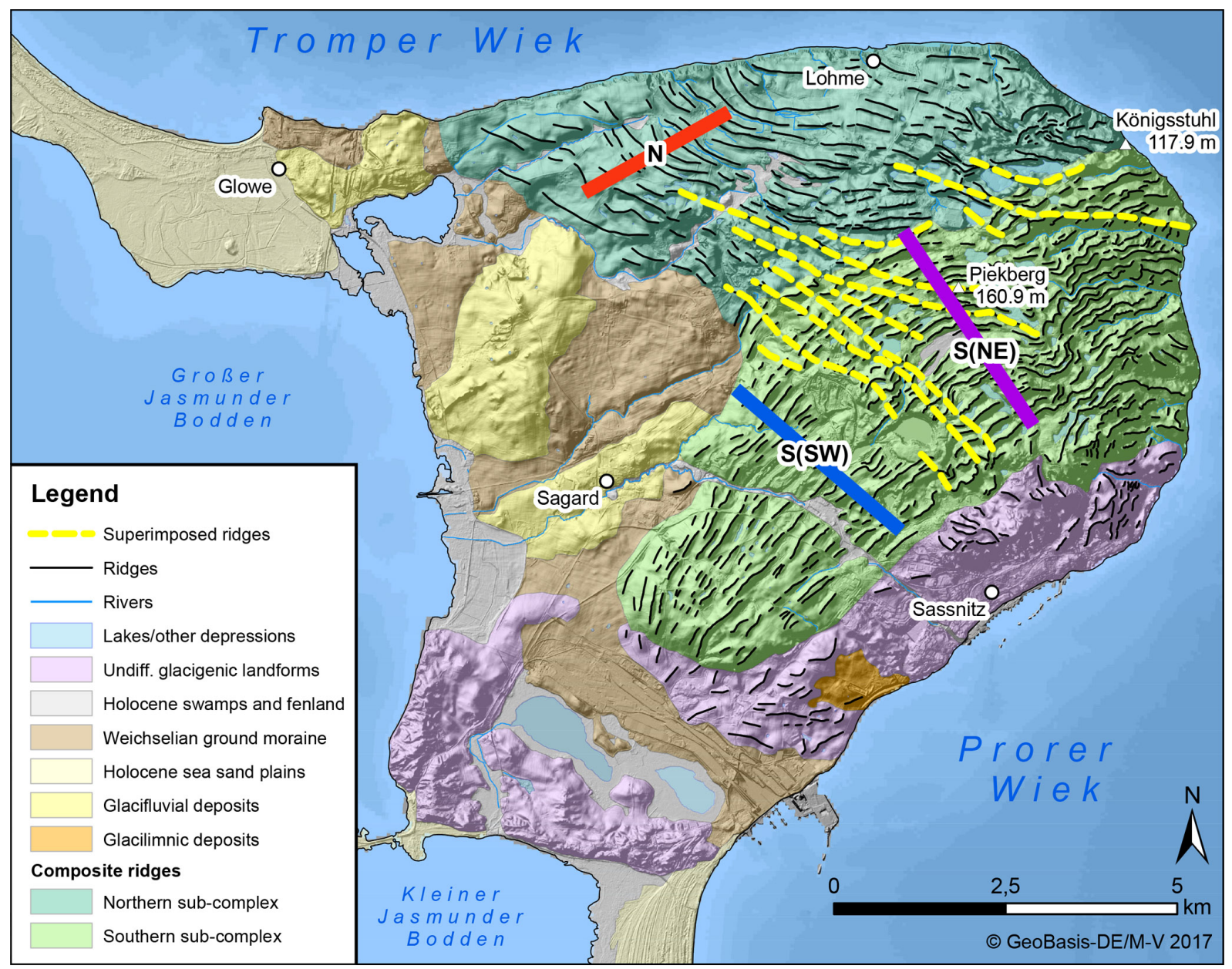

Figure 1. Geomorphological map of the Jasmund peninsula with the hillshaded DEM as background. The surrounding seabed of the Tromper and Prorer Wiek and the Großer and Kleiner Jasmunder Bodden are based on a DEM of the German Baltic Sea (see Tauber, 2012a, b). The profile tracks N, S(SW), and S(NE) show the position of the elevation profiles/periodograms in Fig. 3 (modified following Gehrmann, 2018).

shore to the western bay, and the elongated area between the morphological highs in the south. Holocene sea sand plains connect the Jasmund peninsula with the peninsulas in the NW and SE of Rügen.

\section{Research history and evolutionary models of the Jasmund Glacitectonic Complex}

The tectonic structure and development of Rügen has been investigated for more than a century. An early significant study was published by Credner (1893), who has already illustrated the surface structure of Jasmund, which is composed of differently oriented sets of subparallel ridges (Fig. 2).

Groth (2003) proposed a complex segmentation of the tectonic complex into five structural units, which are assigned to four developmental phases (Fig. 2). Initially, the majority of the southern structural sub-complex was formed by a glacial push from the SE, which was followed by a push from the
$\mathrm{NE} / \mathrm{E}$ that created the northern structural sub-complex and the southern part of the southern sub-complex. The deformation continued with a complicated reorganisation of the southernmost zone (push from the NE) and a final superposition of the entire complex.

Ludwig (1954/55, 2011) instead separated the Jasmund peninsula into three parts - a northern and a southern subcomplex, which are adjacent to a high central zone (Fig. 2). The model suggests a polyphase contraction of the deposits at the confluence between two major ice streams, which were active during the Pomeranian W2 phase. Pressure formed between the two competing flows and resulted in a loopshaped accretion of thrust sheets, eventually forming a compressional arc that is convex to the east. This is thought to have been followed by a westward shift of the southern and northern thrust sheets induced by the increasing ice push.

The analysis of high-resolution digital elevation models (DEMs) derived from lidar data (provided by the LAiV M-V, Landesamt für innere Verwaltung Mecklenburg- 

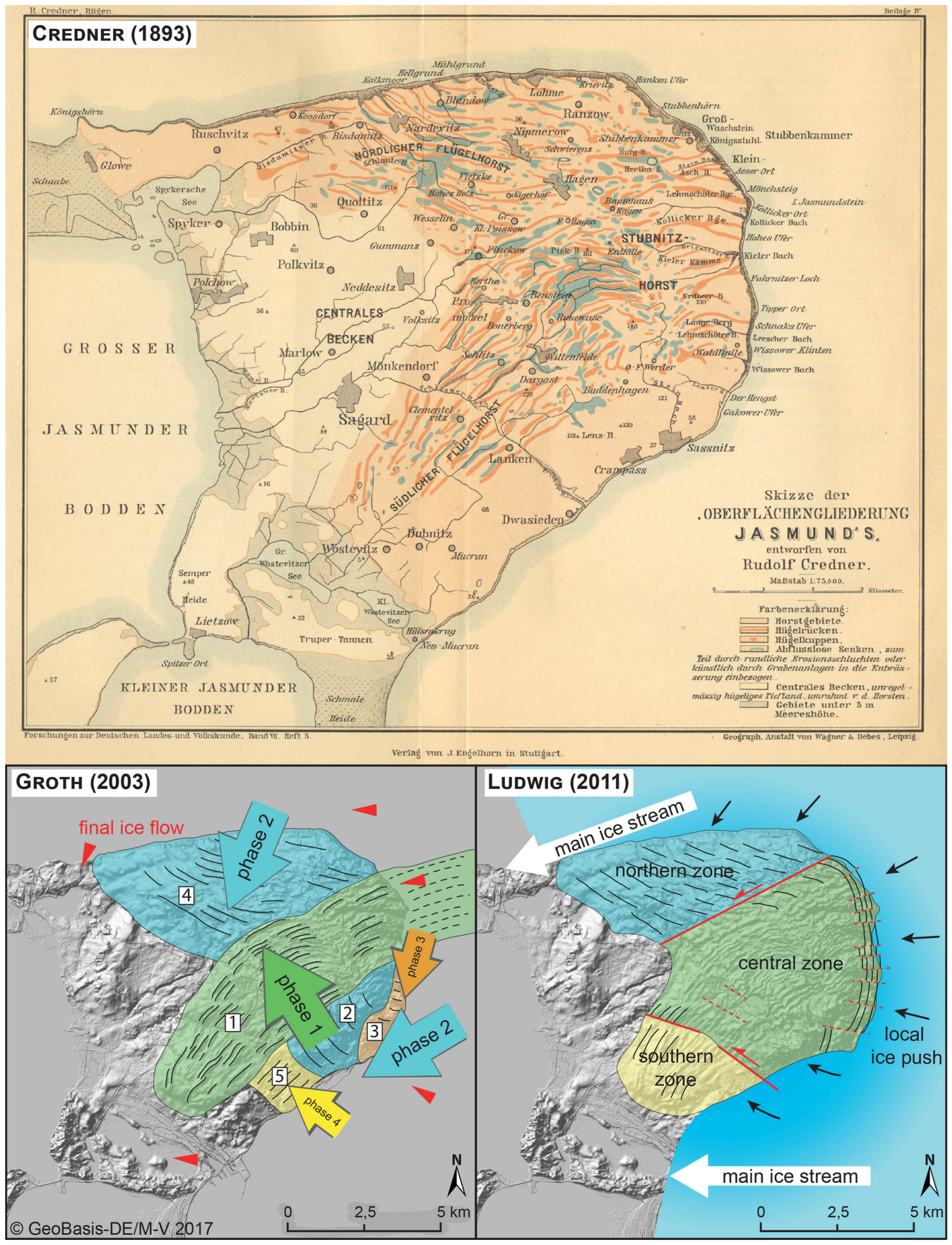

Figure 2. Three major models to interpret the structural conditions and development of the Jasmund peninsula, created by Credner (1893), Groth (2003), and Ludwig (2011). 


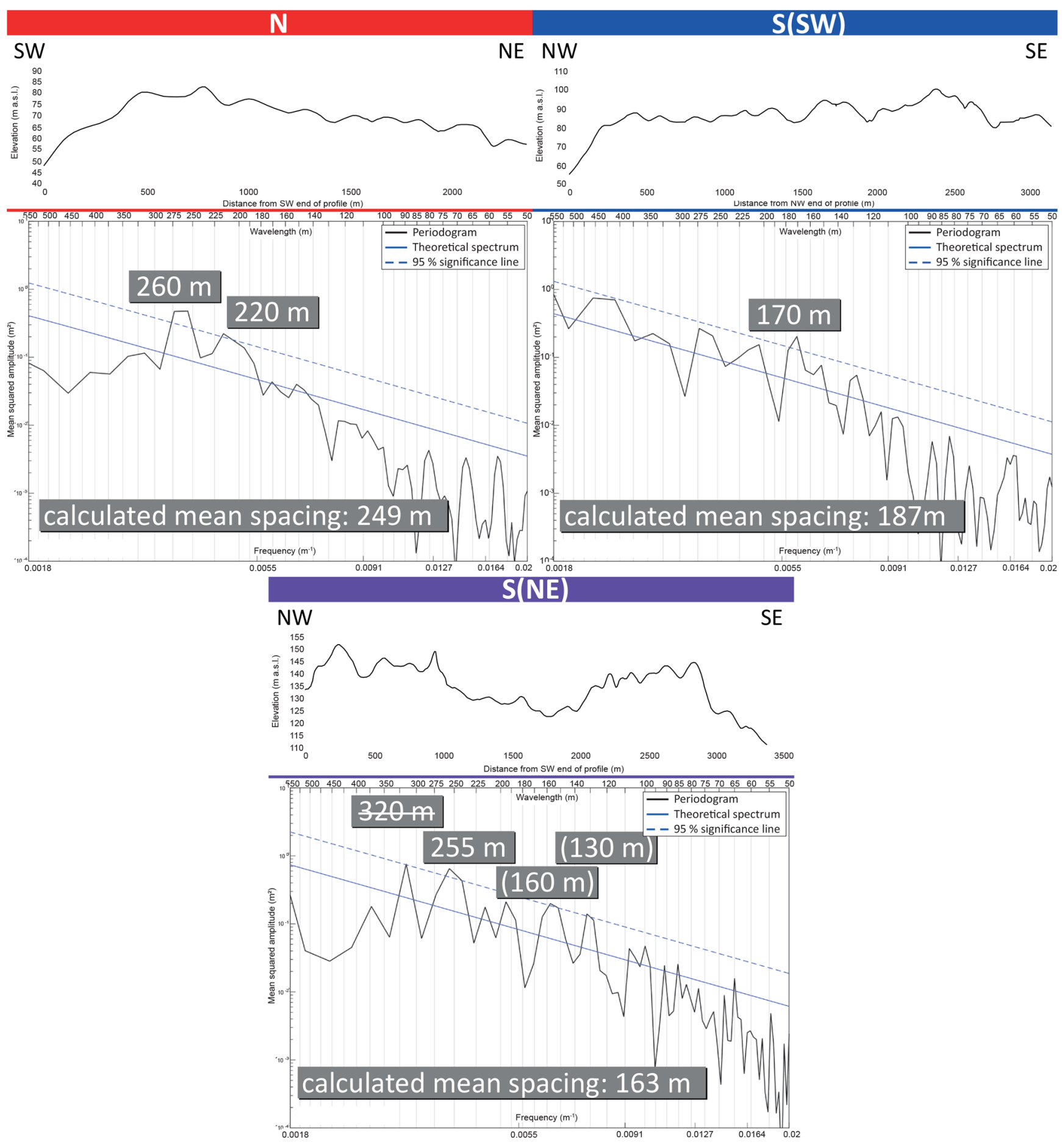

Figure 3. Elevation profiles and related periodograms of the profile tracks $\mathrm{N}$ (northern sub-complex), S(SW) (southwestern part of the southern sub-complex), and S(NE) (northeastern part of the southern sub-complex). The significant wavelengths are shown in grey boxes above the related peak. The struck through value in the $\mathrm{S}(\mathrm{NE})$ periodogram represents an outlier, and the values in parentheses are tangent to the $95 \%$ significance line but still significant. Calculated mean spacing values in grey boxes support the results within the periodograms. The significant wavelengths of the $\mathrm{S}(\mathrm{NE})$ periodogram are representative of both the northern and the ridge domain; thus they indicate a superimposition of the northern sub-complex by the southern one (modified following Gehrmann and Harding, 2018). 


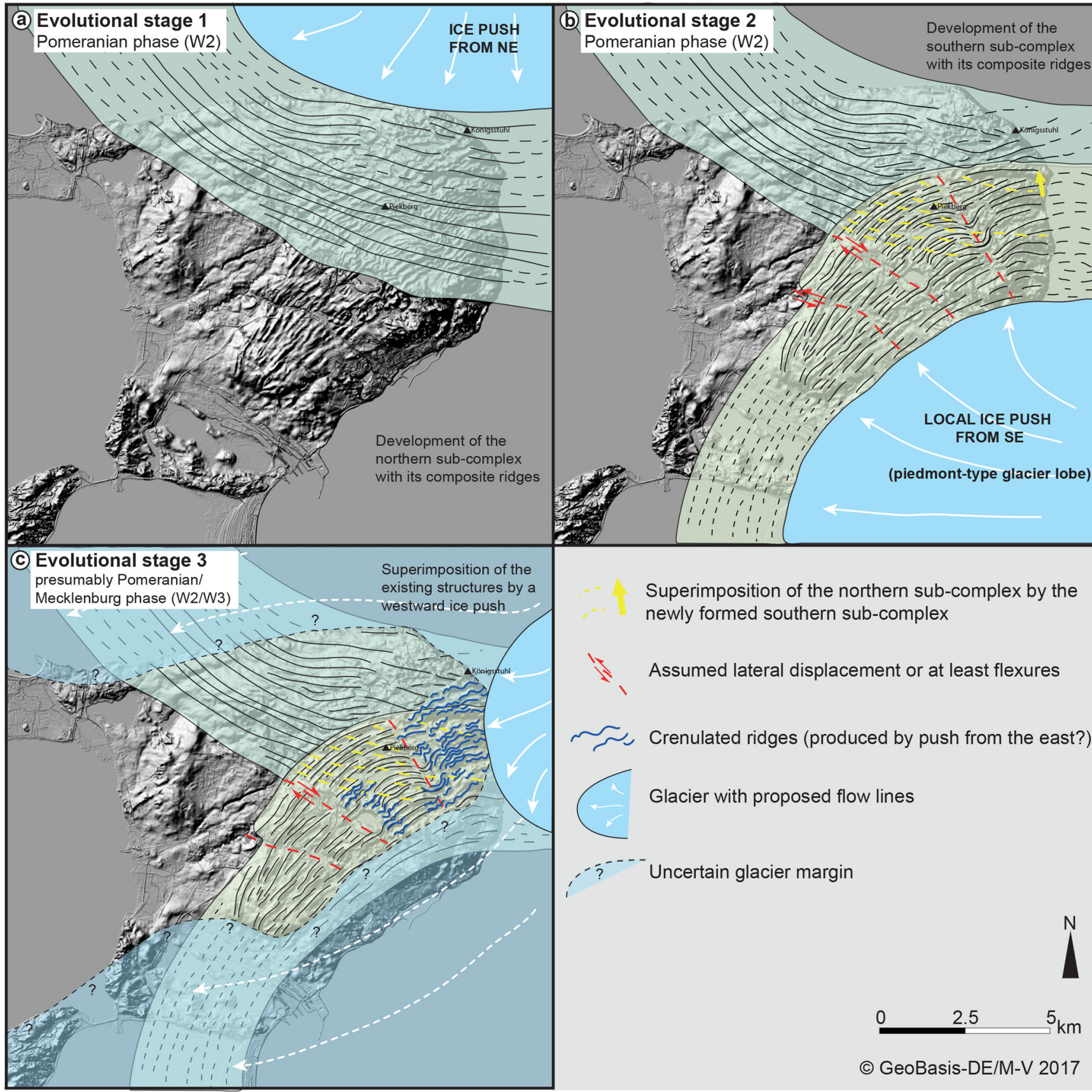

Figure 4. Multi-stage evolutional model of the Jasmund Glacitectonic Complex. (a) Formation of the northern sub-complex by a local ice push from the NE. (b) Development of the southern sub-complex by a local ice push from the SE leading to a partial truncation and superimposition of the northern ridge domain. (c) Minimum reconstruction of the ice front only touching the easternmost part of the glacitectonic complex (light blue) and assumed wider glacier extent, which to some extent envelopes the complex (transparent light blue). The local ice push from E/ENE reshapes the quasi-straight ridges to wavy forms (modified following Gehrmann and Harding, 2018).

Vorpommern) provides a novel research tool for sedimentological and tectonic studies at the Jasmund Glacitectonic Complex (Gehrmann and Harding, 2018). This analysis provides the basis for a re-examination of Jasmund's evolution and the development of a new structural model. The detailed assessment of the ridge morphometry is based on Bradwell et al. (2013), and the terrain analysis using Fourier transformations has been developed from Cline et al. (2015).

A number of transects were constructed in the northern and southern ridge domain perpendicular to the ridge crests (see the examples in Fig. 1). Performing a Fourier analysis of the waves formed by the trough-peak-trough elevation 
changes along each ridge profile creates a frequency domain plot, called a periodogram, which plots the width of the wave (wavelength, trough-to-trough distance) on the $x$ axis and the wavelength spectral power on the $y$ axis (Fig. 3). Peaks of large spectral power values indicate that the peak's wavelength is potentially important. Wavelengths with a spectral power above the $95 \%$ confidence line were considered to be statistically significant, resulting in a set of wavelengths that are dominant for a given profile.

The new evolutionary model created by Gehrmann and Harding (2018) suggests a multi-stage structural evolution for the Jasmund Glacitectonic Complex in the late Weichselian (Pomeranian phase, W2). The periodograms, as shown in Fig. 3, help to reveal the evolution of Jasmund's deformation stages. The dominant wavelength of the composite ridges in the northern sub-complex is about $260 \mathrm{~m}$. The dominant wavelengths in the southern sub-complex are generally smaller, with 135 to $195 \mathrm{~m}$. This could point to slight differences in formation time and mechanisms between the northern and southern ridge domain, with regard to exerted stresses and glacier velocities (Gehrmann and Harding, 2018). The ridges are periodically spaced, which is characteristic of even small fold-and-thrust belts like the Jasmund Glacitectonic Complex (see Benediktsson et al., 2010; Noble and Dixon, 2011) (Fig. 3).

The first evolutionary stage (Fig. 4a) is characterised by a local NE-to-SW push by a branch of the SIS forming the northern structural sub-complex and the related composite ridges. Composite ridges were formed during a single rapid ice advance, which created high pore-water pressure and resulted in extreme compressional deformation at the glacier margin (e.g. Benn and Evans, 2010).

The larger wavelengths of the northern ridge domain of around $260 \mathrm{~m}$ are still present in the eastern part of the southern ridge domain (Fig. 3c). One possible explanation is that this part of the southern ridge domain represents a zone of tectonic superimposition. Hence, the surface structures of the southern sub-complex were superposed over the northern structural sub-complex in a second evolutionary stage (Fig. 4b). A branch of the SIS might have pushed the local glacifluvial deposits from the SE towards the NW. Why the Pomeranian W2 ice stream moved from the SE to NW is still under debate (e.g. Ludwig, 2011; Gehrmann and Harding, 2018). Characteristic cross profiles of composite ridges with steep distal and flat proximal slopes can be observed in the northern sub-complex and in the southwestern district of the southern ridge domain. Ridges in the eastern district are rather symmetric, which is perhaps due to the northern ridge resisting the movement of the southern ridge set.

The ice stream induced a compressional deformation, presumably compensated for by lateral dislocation along slip faults or at least flexures (Fig. 4b). Ludwig (2011) described these structures as a result of a progressive glacier push and westward shift of the southernmost and northern zone of the Jasmund Glacitectonic Complex (see Fig. 2b). Gehrmann and Harding (2018) suggest that the shift along the central (assumedly dextral) fault is connected to the already existing northern sub-complex (see Fig. 4b). Nevertheless, it is possible that late Paleozoic faults (Wiek, Nord Jasmund, and Schaabe fault) played a role in the glacitectonic development of Jasmund, too (see e.g. Steinich, 1972; Seidel et al., 2018; Gehrmann and Harding, 2018).

The crenulated ridge shapes in the eastern district of the Jasmund Glacitectonic Complex may indicate a third evolutionary stage in the form of a local ice push from the E/ENE (Fig. 4c) (Gehrmann and Harding, 2018). Whether the glacier front only touched the eastern ridges of the glacitectonic complex or enveloped the entire complex has yet to be determined. However, the existence of the till complex on top of the glacitectonised sequence in the northern and southern sub-complex is an indicator that the ice eventually overrode the complex or at least its marginal zones.

Data availability. The data are publicly available via the thesis Gehrmann (2018) and the references therein online at https://nbn-resolving.org/urn:nbn:de:gbv:9-opus-24751 (last access: 22 July 2019).

Author contributions. $\mathrm{CH}$ and AG conceived and designed the methodology, performed the analysis, and wrote the article.

Competing interests. The authors declare that they have no conflict of interest.

Acknowledgements. We thank the Landesamt für innere Verwaltung Mecklenburg-Vorpommern, Abt. 3: Amt für Geoinformation, Vermessung und Katasterwesen (LAiV) for providing the lidar data and Jörg Hartleib for processing the lidar data and providing the DEM of Jasmund. In addition, he is thanked for a critical review of the contribution. We acknowledge support for the article processing charge from the DFG (no. 393148499) and the Open Access Publication Fund of the University of Greifswald.

Financial support. This research has been supported by the DFG (German Research Foundation, grant no. 393148499) and the Open Access Publication Fund of the University of Greifswald.

\section{References}

Benediktsson, Í. Ö., Schomacker, A., Lokrantz, H., and Ingólfsson, Ó.: The 1890 surge end moraine at Eyjabakkajökull, Iceland: a re-assessment of a classic glaciotectonic locality, Quaternary Sci. Rev., 29, 484-506, https://doi.org/10.1016/j.quascirev.2009.10.004, 2010.

Benn, D. I. and Evans, D. J. A.: Glaciers and Glaciation, Hodder Education, London, UK, 2010. 
Bradwell, T., Siggurðsson, O., and Everest, J.: Recent, very rapid retreat of a temperate glacier in SE Iceland, Boreas, 42, 959-973, https://doi.org/10.1111/bor.12014, 2013.

Cline, M., Iverson, N., and Harding, C.: Origin of washboard moraines of the Des Moines Lobe: Spatial analyses with LiDAR data, Geomorphology, 246, 570-578, https://doi.org/10.1016/j.geomorph.2015.07.021, 2015.

Credner, R.: Rügen. Eine Inselstudie, Forschungen zur deutschen Landes- und Volkskunde, 7, 373-494, 1893.

Gehrmann, A.: The multi-stage structural development of the Upper Weichselian Jasmund Glacitectonic Complex (Rügen, NE Germany), Dissertation, Faculty of Mathematics and Natural Sciences, University of Greifswald, Germany, 2018.

Gehrmann, A. and Harding, C.: Geomorphological Mapping and Spatial Analyses of an Upper Weichselian Glacitectonic Complex based on LiDAR Data, Jasmund Peninsula (NE Rügen), Germany, Geosciences, 8, 1-24, https://doi.org/10.3390/geosciences8060208, 2018.

Gehrmann, A., Hüneke, H., Meschede, M., and Phillips, E. R.: 3D microstructural architecture of deformed glacigenic sediments associated with large-scale glacitectonism, Jasmund Peninsula (NE Rügen), Germany, J. Quaternary Sci., 32, 213 230, https://doi.org/10.1002/jqs.2843, 2017.

Groth, K.: Zur glazitektonischen Entwicklung der Stauchmoräne Jasmund/Rügen, Schriftenreihe des Landesamtes für Umwelt, Naturschutz und Geologie Mecklenburg-Vorpommern, 3, 39-49, 2003.

Litt, T., Behre, K.-E., and Meyer, K.-D.: Stratigraphische Begriffe für das Quartär des norddeutschen Vereisungsgebietes, Eiszeitalter und Gegenwart, 56, 7-65, https://doi.org/10.23689/fidgeo1278, 2007.

Ludwig, A. O.: Eistektonik und echte Tektonik in Ost-Rügen (Jasmund), Wissenschaftliche Zeitschrift der Ernst-Moritz-ArndtUniversität Greifswald, Mathematisch-naturwissenschaftliche Reihe, 4, 251-288, 1954/55.

Ludwig, A. O.: Zwei markante Stauchmoränen: Peski/Belorussland und Jasmund, Ostseeinsel Rügen/Nordostdeutschland - Gemeinsame Merkmale und Unterschiede, E\&G Quaternary Sci. J., 60, 31, https://doi.org/10.3285/eg.60.4.06, 2011.
Müller, U. and Obst, K: Lithostratigraphie und Lagerungsverhältnisse der pleistozänen Schichten im Gebiet von Lohme (Jasmund/Rügen), Zeit. geol. Wissenschaft., 34, 39-54, 2006.

Niedermeyer, R.-O., Kanter, L., Kenzler, M., Panzig, W.-A., Krienke, K., Ludwig, A. O., Schnick, H. H., and Schütze, K.: Die Insel Rügen (I) - Fazies, Stratigraphie, Lagerungsverhältnisse und geologisches Gefahrenpotenzial pleistozäner Sedimente der Steilküste Jasmund, in: Eiszeitlandschaften in MecklenburgVorpommern. Exkursionsführer zur 35. Hauptversammlung der Deutschen Quartärvereinigung DEUQUA e.V. und der 12. Jahrestagung der INQUA PeriBaltic Working Group in Greifswald/Mecklenburg-Vorpommern, 13-17 September 2010, Greifswald, Germany, edited by: Lampe, R. and Lorenz, S., Geozon, Greifswald, Germany, 51, https://doi.org/10.3285/g0005, 2010.

Noble T. E. and Dixon, J. M.: Structural evolution of fold-thrust structures in analog models deformed in a large geotechnical centrifuge, J. Struct. Geol., 33, 62-77, https://doi.org/10.1016/j.jsg.2010.12.007, 2011.

Paulson, C.: Die Karstmoore in der Kreidelandschaft des Nationalparks Jasmund auf Rügen, Greifswalder Geographische Arbeiten, 21, 59-271, https://doi.org/10.23689/fidgeo-1978, 2001.

Seidel, E., Meschede, M., and Obst, K.: The Wiek Fault System east of Rügen Island: origin, tectonic phases and its relationship to the Trans-European Suture Zone, in: Mesozoic Resource Potential in the Southern Permian Basin, edited by: Kilhams, B., Kukla, P. A., Mazur, S., McKie, T., Mijnlieff, H. F., and van Ojik, K., Geological Society of London Special Publications, 469, https://doi.org/10.1144/SP469.10, 2018.

Steinich, G.: Endogene Tektonik in den Unter-MaastrichtVorkommen auf Jasmund (Rügen), Supplement 71/72, Geologie, 20, 1-207, 1972.

Tauber, F.: Seabed relief in the German Baltic Sea: Arkona, Map 2946, $1: 100000,54^{\circ} \mathrm{N}$, Bundesamt für Seeschifffahrt und Hydrographie, Hamburg, Germany, 2012a.

Tauber, F.: Seabed relief in the German Baltic Sea: Pomeranian Bight, Map 2949 1:100000, 54 N, Bundesamt für Seeschifffahrt und Hydrographie, Hamburg, Germany, 2012b. 